\title{
Evaluating the impact of heterotrophic bacteria on ocean iron cycling
}

\author{
ANH LE-DUY PHAM ${ }^{1}$, OLIVIER AUMONT ${ }^{1}$, LAVENIA \\ RATNARAJAH ${ }^{2}$ AND ALESSANDRO TAGLIABUE ${ }^{2}$ \\ ${ }^{1}$ Laboratoire d'Océanographie et du Climat: Expérimentations et \\ Approches Numériques (LOCEAN), IRD-IPSL, Paris, France \\ ${ }^{2}$ University of Liverpool \\ Presenting Author: anh.pham@locean-ipsl.upmc.fr
}

Heterotrophic bacteria (bacteria) can play a key role in the ocean cycling of essential biogeochemical elements, including iron $(\mathrm{Fe})$, via their uptake, transformation, and release of organic matter throughout the water column. In addition, bacteria require $\mathrm{Fe}$ for their growth, thereby potentially becoming a competitor with phytoplankton for this resource in the upper ocean. Furthermore, as an important prey for zooplankton, bacteria can transfer Fe up the food chain, thus potentially altering the vertical remineralization profile of $\mathrm{Fe}$. However, the impact of bacteria on ocean Fe cycling and ocean biogeochemistry at the global scale has not yet been evaluated and is still poorly understood due to limited observations. In this study, we address this issue by explicitly representing the bacteria biomass and their Fe quota in a three-dimensional global ocean biogeochemistry model. The results show that the bacterial growth is limited by $\mathrm{Fe}$ in the tropical Pacific and high-latitude ocean regions and that bacterial Fe demand controls the magnitude of the phytoplankton bloom and carbon export in those regions. In addition, the bacterial impact on the subsurface ocean Fe cycling is minor due to a tight coupling between bacterial Fe uptake and release. 